\title{
Assessment of Turkish Ceramic Manufacturing Companies’ Competitiveness and Compatibilities to EU in Consideration of Porter's Five Forces Model
}

\begin{abstract}
A. ELEREN, C. YILMAZ
Afyonkocatepe University, Afyon, Turkey

As an EU candidate, Turkey and Turkish firms have to prepare and enhance their competitiveness, and have to be more compatible to EU states' economies for full membership and unification. This study is trying to assess the Turkish ceramic industry's position in the light of Porter's framework. Since the publication of competitive strategy: techniques for analyzing industries and competitors by Porter in 1980, his frameworks are still considered as reliable however some criticisms still exist. Questionnaire applied to the firms which include questions related to three main topics: qualitative and quantitative information related to firm characteristics; firms' internal strengths related to finance, production, and managerial aspects etc.; and LIKERT scale based on Porter's frame. Results of the study: managerial structures are less professional; manufacturing technologies are old; there is a need for use of advanced managerial techniques such as TQM, JIT etc.; lower rate of direct exportation (they usually export via third parties); less clustering activities; and innovative activities are not enough for more competitive environment.
\end{abstract}

Keywords: competitiveness, EU, SME, ceramic sector, sector analyze, Porter, internal strengths

\section{Introduction}

Traditionally, it is believed that success of the firms relies on its ability adapt to market conditions. For example, Bain (1968) suggested firms' strategy should rely on industry's structural forces for success. Such thinking mainly concentrates on evolution of industry. In contrast to traditional thinking, Porter in his studies mainly concentrated on firms' internal efficiencies and capabilities that could create core competencies during the strategy set up process. But Porter (1980) did not neglect the forces influencing market conditions-five competitive forces model. Competitive market forces are discussed in several studies (Boulding et al., 1994). Porac and Thomas (1990) mentioned that managers usually focus on certain information which they thought it is critical, and they make their decisions and performance measurements on this basis. Miller and Freisen (1984) suggested business environment could affect the business strategy.

This study suggests that understanding the business environment and its competitive forces might lead the firms to design better strategies and to success. Ceramic sector, traditionally, is a strong and competitive sector

A. ELEREN, Associated Professor, Doctor, Business administration, Afyonkocatepe University.

C. YILMAZ, Assistant Professor, Doctor, Business administration, Afyonkocatepe University.

Correspondence concerning this article should be addressed to C. YILMAZ, A.K.Ü., İ.İ.B.F., ANS kampusu, egitim-3, Afyon/Turkey. E-mail: ylmzcc@yahoo.com. 
in Turkey. But changing competitive environment is forcing them critically. In the global competitive environment, decision-makers have to make adoptions and redesign their strategies. The study includes analyses which examine the competitive forces of Turkish ceramic sector in the light of Porter's five forces model.

\section{Competitive Powers}

In today's global economy, there are several factors or forces that affect the success of strategic decisions. Strategists have to take their decisions according to their positions by assessing their own positions. One might describe competitive powers as "strategic tools that are enhancing companies' competitiveness". There could be numerous competitive powers and they vary in according to firms' positions and strategic choices. Determining and using of these powers and implementing into a strategic choices might be quite complex because of cultural traits (Hitt, Dacin, Tyler, \& Park, 1997; Ralston, Gustafson, Cheung, \& Terpstra, 1993).

Competitive powers' importance might vary in according to environment where the company survives. So the factors such as cultural traits, geographical placement might increase or decrease the importance of the competitive powers. That is why there are several definitions that are trying to define the term "competitive powers".

Peteraf (1993) defined competitive forces as ability to generate supplementary income rather than the average earnings; Scoot and Lodge (1985) defined competitive forces as ability to increase income of a nation while increasing production of goods and services to be exported to other nations; Hatsaopulos, Krugman, and Summer (1988) defined competitive forces as ability to provide significant income increase. These and similar other definitions mainly concentrated on increased efficiency and income. In addition to these factors, European Commission (1994) highlighted the importance of ability to create new jobs in the economy.

Porter (1998) suggested that nations could gain competitive powers by using their sources optimally, and for optimal usage, they have to focus on certain sectors and create specialized clusters on these sectors. With the globalization, studies related to measuring and increasing competitive powers became more popular among the academics. Reel currency calculations are the most popular methods to assess competitive powers. In addition to these indicators, Kotan (2002) suggested factors like inflation rate, wage levels, unemployment rate, efficient usage of men power, new investments, and trained workforce and research and development facilities could also influence the competitive powers of firms or nations.

\section{Factors Influencing Competitive Powers}

There are several factors influencing the competitive powers of a firm, for example, balance between cost and quality, product diversity, design, esthetics, packaging, technology, efficiency, flexible production methods etc.. These factors could be classified under two headings: internal factors and external factors (Eroğlu \& Özdamar, 2006).

Quality, price, efficiency, profitability, Technological level, speed, and timing are the internal factors influencing the competitive powers of a company. Additionally, product development capabilities and flexible production methods are also can be considered as internal factors.

Whereas, external factors could be listed as follows: rivals' competitive power, market instability, logistic capabilities market, availability of subcontractors, sources of nation, efficiency of local financial market, transportation network, and the level of economical and political development. 


\section{Porter's Five Forces Model}

Porter's (1980) five forces model is one of the most respected models in the literature to assess the competitive environment. Porter classifies limitless different competitive forces, which affect the competitive power, under five headings: the rivalry between existing competitors; the threat of new entrants; the threat of substitute products; the bargaining power of suppliers; and the bargaining power of buyers.

Figure 1 represents important factors that can critically enhance a country's or a company's competitiveness. Strength in human capital might augment the internal efficiency as well as external efficiency. Efficient usage of technological knowledge can critically reduce the company's costs or improve the quality of products. New innovations (products) might make the company leader in the sector. In the competitive sectors managerial capabilities can be extremely important even to survive in the sector. However lacking financial resources defects in economical climate or in infrastructure critically might reduce the competitiveness of companies.

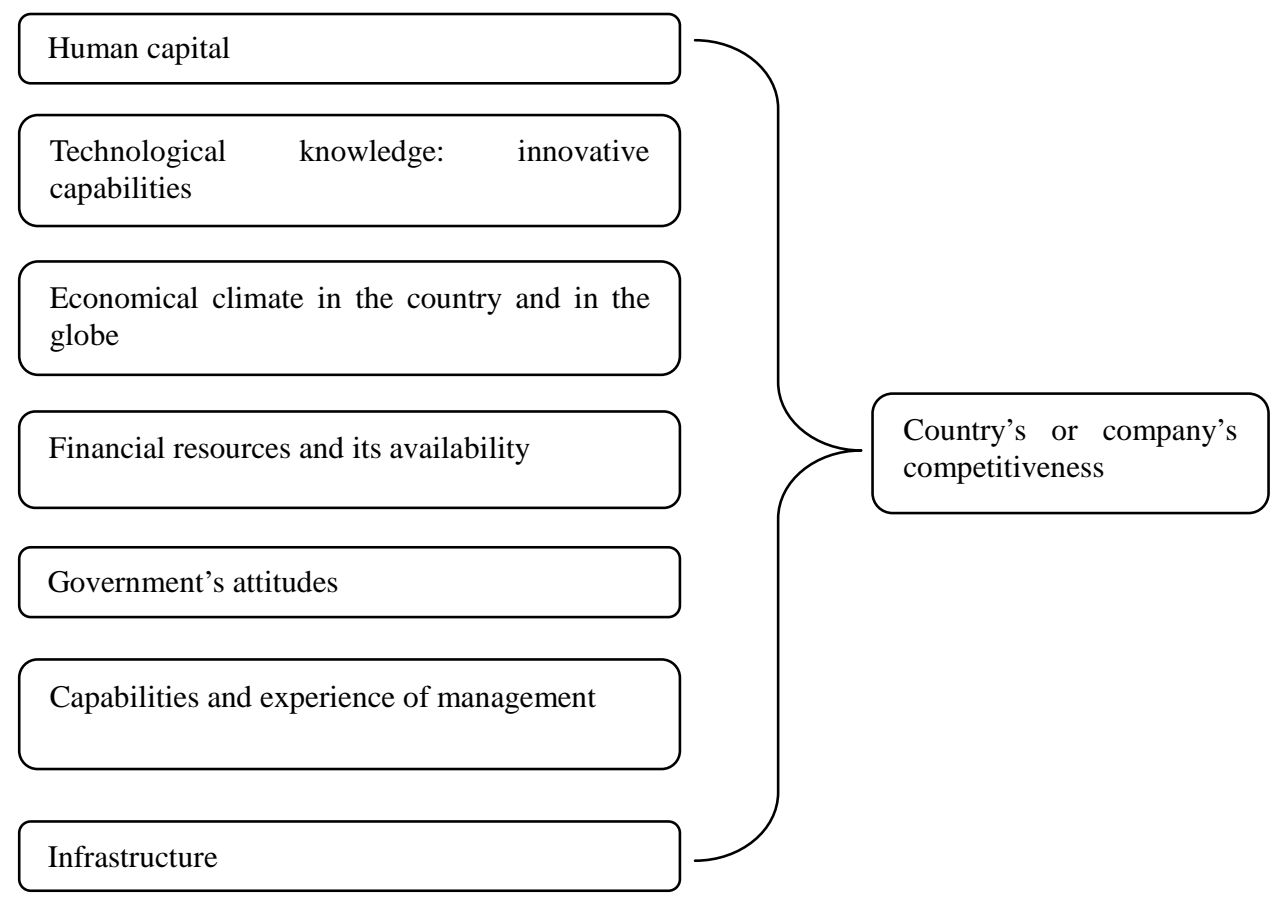

Figure 1. Factors affecting competitive power of a company.

Figure 2, illustrates Porters five forces. These are: the rivalry between existing competitors, the threat of new entrants, and the threat of substitute products, the bargaining power of suppliers and the bargaining power of buyers.

The rivalry between existing competitors. As industry becomes more mature competition increases among the rivals, selective demand intensifies and companies start to invest in incremental product innovations (Kotler, 2000), hence, the attractions of industry weakens. During intensified competition, companies usually go for differentiated products and use focus or niche strategies. On the other hand, immature industry attracts more new comers because immature sectors provide more opportunities for new comers, more control on pricing, less competition etc..

The threat of new entrants. The threat of new entrants is higher during the growing phase of the industry. 
During the growing phase, existing firms' profits are increasing. That is why sector attracts the other investors and is considered as emerging market. When the new entrants become a threat for existing firms, strategies swifts from primary demand to selective demand and they start to focus on certain customer segments (Utterback \& Abernathy, 1975; Mansfield, 1993). In this period, prices go down and efforts for efficiency increase.

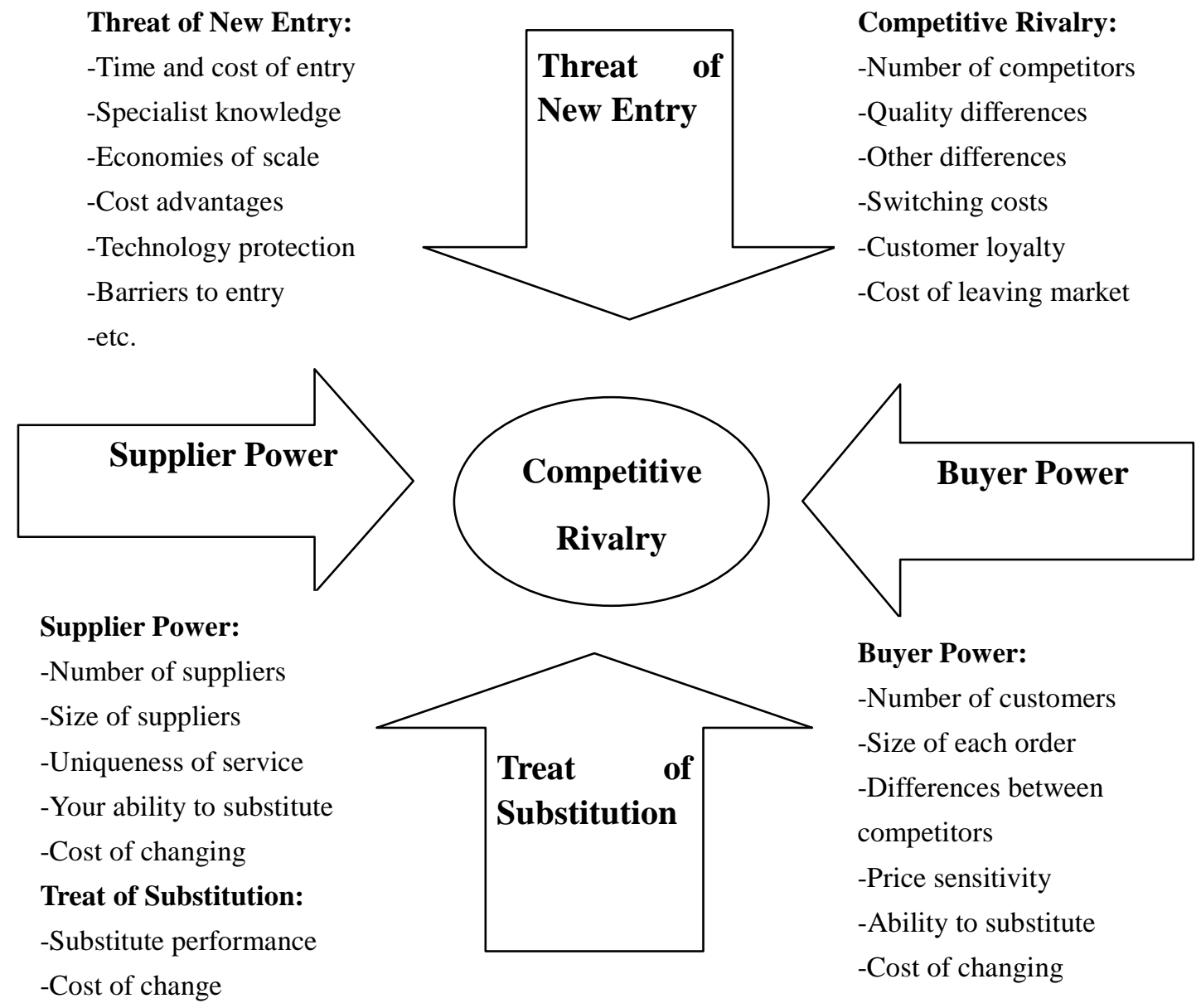

Figure 2. Porter's five forces. Source: Retrieved from http://www.mindtools.com/pages/article/newTMC_08.htm.

The threat of substitute products. The threat of substitute products can limit the control of the firm on pricing and limit the profitability of industry. Cost leadership strategy or creating brand loyalty would be the choices for existing firms. Porter (1980) and Scherer and Ross (1990) suggested reducing alternative product types’ prices would be a good defensive strategy in the long term.

The bargaining power of suppliers. The bargaining power of suppliers is the ability to determine different prices and the capability to charge them to different buyers, when the suppliers have advantageous position against to buyers (Porter, 1989, 1996). If the price of a product is heavily determined by the suppliers this means suppliers have higher bargaining power. Capability of determining prices can critically affect the profitability of a firm. Suppliers who have higher bargaining power can critically limit the buyers' profitability with higher prices. 
The bargaining power of buyers. The bargaining power of buyers is the other side of the coin. In this case, buyers have power to determine the prices and limit the profits of suppliers, if buyers have higher bargaining power.

Porter indicates that analyzing of these forces might help to the managers who are seeking to have better positioning which is important for success in the long term. Healthy analyses of five forces could lead the managers better strategic choices: cost leadership, differentiation, or focus (or their combinations).

Strategic planning and analyzing are the main areas that Porter interested in. With customary methods, the information which is used during strategic analyses is mostly not precise or uncertain. In addition to this, the characteristics of data used in different analyses mostly do not match with each other. Consequently, their results usually are not comparable.

However, Porter's five forces model more exhibits how various factors affect the profitability of a company (Arons \& Waalewijn, 2000). This model focuses on perception of management about the relationship between the environment and the strategy based on this environment. Firm's strategies and performance depend on industry's structure. So, the attractiveness of an industry relies on the threats and opportunities. On the other hand, average performance of firms in attractive industries would be higher than the less attractive industries (Sultan, 2007). Chaffey (2002) indicated that Porter's five forces model could still be used as a framework to examining the e-business sector.

Besides, Porter's model can be used for assessing the business environment-rivals' positioning, their offensive and defensive tactics and general business climate (static analysis), and therefore decision-makers could create more realistic scenarios for the future decisions (dynamic analysis).

\section{Basics of Research Framework}

Searches, in Turkey, mainly concentrated on existing economical problems of SMEs and ceramic sector. These studies mostly neglected the competitive power of companies and future perspectives of them. The author's study is trying to examine the existing situation and trying to appraise the future.

Aim of the study is to find out the degree of competitive forces in Turkish ceramic sector which might provide information to assess the threats and opportunities related to industry. Results of the study would be used for improvement purposes. Scope of the study is limited by Turkish ceramic companies.

\section{Limitations and Deficiencies of the Study}

The study is a statistical study. That is why it has defects that any statistical study might have, such as, it is a domestic study that results are only representing the Turkish ceramic sectors characteristics. Furthermore, some firms did not respond to the study and some are excluded from the study because of their extra ordinary results.

Study represents the views of manager/owners, which does not mean these views are unquestionable facts. There are several theorems and thoughts in the literature that could explain the similar results in a very different ways.

In addition to these, study has started just before the global crises when the Turkish economy and ceramic sector have not fully been affected. So the study does not represent the effects of global crises.

\section{Scale of the Search}

Demographic information. Demographic information is gathered from the questionnaire questions which 
includes 50 (multiple choice and ranking scale) questions that applied to 73 Turkish ceramic companies (out of 259 company). Nine of them are eliminated because of inappropriate results. Additionally, face to face interviews applied to these companies' owners of managers. Responses to these questions provided us data related to their fields of activities, legal structure, manpower, and turnover, in addition to their managerial, financial, and marketing activities.

Scale of competitiveness. Our scales of competitiveness is designed on the basis of Porter's (1985); Certo and Peter's (1995); Dess and Miller's (1996); and mostly Coşkun's (2001) scales. The spirit of original scale is prevented while some questions are added which critically elucidates the internal dynamics of company. This scale was firstly applied in a study by Eleren and Kayahan (2008) which was used for analyzing regional development. In this study, reliability rate of scales (Cronbach’s alpha) found 79.16\%.

Distribution of questions as follows: perception of potential threats (nine questions); perception of intensity of competition (12 questions); perception of threat of substitute goods (seven questions); evaluation of bargaining power of buyers (nine questions); and evaluation of bargaining power of sellers (12 questions).

Reliability test of the scale. Scale is tested with SSPS program and the results of Cronbach's alpha found $86.13 \%$.

\section{Evaluation of Research Findings}

Research findings assed under three headings: general classifications of firms; assessment of internal competitiveness; and analysis of ceramic companies according to Porter's five forces scale.

\section{General Classification of Firms}

Geographic concentrations of the firms are mainly centered in three cities: with $18.8 \%$ Istanbul is having the highest concentration, and then followed by $10 \%$ in Kütahya and Çanakkale. This is may be because of ceramic companies' prefer to establish their factories in such places that close to raw material and market places. In terms of distance to raw material and market, these cities are strategically important for ceramic companies.

Sixty two point five percent of the firms are SMEs who produce tiles and tile products and work as sole companies. They are processing the finished goods, ornamenting and garnishing them. Obviously, they are labor intensive firms. These small firms are mostly family owned firms.

In terms of partnership, there are two main characteristic features: they are mainly family owned partnerships (usually two to five partners); and board of management usually consists of family members.

Definition of Turkish trade and industry ministry describes the SMEs under three headings: number of workers; amounts of capital investment; and annual turnover. Measures are applied according to this definition.

According to labor force criterion, 56.3\% of the firms (subjected to the search) can be considered as SMEs which is inconsistent with turnover (93.8\% considered as SMEs) and capital (90.6\% considered as SMEs) criterions. In consideration of both criterions, sector is mainly dominated by the SMEs.

\section{Assessment of Internal Competitiveness of the Firms}

The highest portion (23.4\%) of the firms' objective is to be the leader in the sector. This is followed by being an integrated part of a production chain. The small amount of the firms is trying to keep on working as subcontractors.

Survey results indicate that majority of the firms are concentrated on international markets rather than 
internal markets. Furthermore they prefer to expand vertically rather than horizontally. Recently, vertical or horizontal integration among the sector has risen to $42 \%$, this indicates that efforts to create more efficient cluster in the sector are also intensified which indicates that they are trying to enhance their internal competitiveness.

The management structure of sector is becoming more and more professional, and $79.9 \%$ of the companies are using professional managers including $25 \%$ of the owners completely leaving the management to professionals, $73.8 \%$ of the managers are undergraduate, and $17.3 \%$ of them are postgraduate from a university.

As a strategic target, $68.8 \%$ of the firms declared that their main target is customers' satisfaction. Whereas $12.5 \%$ of them indicated that their main target is to reach a total quality management.

While producing diamond (square cement) or vitrified mass production methods is used widely. Limited numbers of firms are using methods like JIT (Just in Time) and FMS (Flexible Manufacturing Systems). Almost all of the big companies are using information technologies widely.

Their rate of capacity utilization is $85.9 \%$ all along firms, contributed to the search. This rate can be considered as high. But the majority of the firms (81.3\%) do not have any patent rights and only a small amount of them having one or two patent rights that indicates there is a weakness in product development.

Recent developments in international trade especially invasion of cheap Chinese products require more efforts for product development facilities. Product development facilities could strengthen the firms' internal competitiveness.

Applications related to total quality management are relatively high with $78.1 \%$. This is a good sign for their internal competitiveness.

Adaptation to technologic breakthroughs is relatively high: $25 \%$ of the companies are using newer technologies (younger than five years old); But a large portion of the firms (73.4) are using technology comparatively older technology up to 15 years old; Only 1.6\% of the firms prefer to traditional production methods and they suggest that these traditional methods providing them competitive advantages in such targeted markets - where the customers are looking for old styles and traditional products.

There is a direct relationship between the age of the firms and their adaptation to technological breakthroughs $(p=0<0.02)$. This is because majority of the firms are established within in the last 15 years and they are using the technology when they are established.

\section{Analysis of Ceramic Companies According to Porter's Five Forces Scale}

On the basis of Porter's five forces model, five groups of questions were acquired from Turkish ceramic companies. These groups were composed of: perception of potential threats (Group 1); perception of density of competition between the rivals (Group 2); perception of threats from substitute goods (Group 3); evaluation of bargaining power of buyers (Group 4); and evaluation of bargaining power of sellers (Group 5).

\section{Hypotheses}

Hypothesis $\mathrm{H}_{1}$ (1): there is a difference between the sector and its sub-sectors. Relationship between the sector and its sectors are tested with ANOVA test. According to test results, significance levels $(p)$ of the groups vary between $0.757,0.837,0.028,0.046$, and 0.841 respectively. Since the third and fourth groups' significance levels are low, the hypothesis $H_{1}(1)$ is rejected and $H_{0}(1)$ is accepted. 
Hypothesis $\mathrm{H}_{1}(2)$ : there is a direct relation between the sizes of firms and their competitiveness. Here the authors used three factors to measure scale of the firms: labor force; capital; and turnover.

1. In terms of labor force: there is a significant difference $(p<0.05)$ between the labor sizes. Companies with higher labor force are more competitive than the smaller ones. There is a direct relation between the number of employees of firms and their competitiveness.

2. There are significant differences between the small firms and big firms in terms of capital size in first and third group. But results of second, fourth, and fifth group questions do not exhibit a significant difference between small firms and big firms in terms of capital size. So the size of capital is not a significant determinant of competitiveness in ceramic sector: $\mathrm{H}_{1}(2)$ is rejected in terms of capital size.

3. Turnover size is also not having a criterion which affects the competitiveness of firms. Results of the first and third group represent a significant difference between the small firms and bigger ones. $\mathrm{H}_{1}(2)$ is rejected in terms of turnover size.

Hypothesis $\mathrm{H}_{1}$ (3): legal structure of the companies makes differences in terms of competitiveness. For this hypothesis significance levels are low: $0.001,0.048,0.047,0.001$, and 0.001 respectively. That is why $\mathrm{H}_{1}(3)$ is rejected since there is no meaningful relation. Legal structure of the companies does not make difference.

Hypothesis $\mathrm{H}_{1}(4)$ : there is a difference between the management structures. ANOVA test results $(p)$ levels of the groups are $0.025,0.002,0.000,0.015$, and 0.032 respectively.

\section{Evaluation of Group Questions Belong to Competition Scale}

Question inquired with the participants grouped in five headings: perception of potential threats; perception of intensity of competition; perception of threat of substitute goods; evaluation of bargaining power of buyers; and evaluation of bargaining power of sellers.

Perception of potential threats. Nine questions were asked related to perception of potential threats of firms and told them to mark, to what extent they fell like the related factor is a threat. The highest level of threat is considered as 5 and the lowest threat is 1 . As it can be seen in Table 1, the biggest threat is product diversity. In the sector, there are many firms competing with each other as well as many international competitors and their range of products are almost uncountable. To cope with that, much of product is threatening the firms. This is also related to the second question ability of rivals firms to develop new product. Obviously, that much of product diversity in the market can be related to rival firms' high capabilities to develop new products. Search results also support that existing firms feeling threatened by their new product development capabilities. But there is a dilemma: firms are highly threatened by the product diversity and the capabilities of rival firms' product development; on the other hand, they invest modest amount of money in research and development facilities. The threats of other factors: growth of the market; rival firms' influences on market; and risk of new start-ups threatens them relatively lower than the previous ones.

Perception of intensity of competition. Interestingly, the biggest threat to firms is the growth of the industry (which is thought to be an opportunity) and possibility of shrinking of market that is not considered as a big threat. But surprisingly they did not affect too much from the global crises (yet) like other sectors.

The second biggest threat for them is the existing fierce competition. Characteristics of sector enable small firms to compete with big firms, local producers with international producers, and high technology users with traditional technology users. That is why, majority of them think that the competition in the sector is "fierce" or "destructive" competition. 
Table 1

Perception of Potential Threats

\begin{tabular}{|c|c|c|c|c|c|c|c|c|}
\hline & $N$ & Aver. & Std. Dev. & 1 & 2 & 3 & 4 & 5 \\
\hline Product diversity & 64 & 3.69 & 1.194 & 6.4 & 9.4 & 25.0 & 28.1 & 31.3 \\
\hline Rivals ability to innovate & 64 & 3.59 & 1.123 & 3.1 & 15.6 & 25.0 & 31.3 & 25.0 \\
\hline Government policies & 64 & 3.47 & 1.208 & 9.4 & 6.3 & 37.5 & 21.9 & 25.0 \\
\hline Growth of the market & 64 & 3.41 & 0.988 & 3.1 & 9.4 & 48.4 & 21.9 & 17.2 \\
\hline Rival firms' influences on market & 64 & 3.40 & 1.205 & 12.5 & 6.3 & 25.0 & 40.6 & 15.6 \\
\hline Risk of new start-ups & 64 & 3.25 & 1.512 & 12.5 & 18.8 & 28.1 & 25.0 & 15.6 \\
\hline Size of capital & 64 & 3.17 & 1.017 & 6.3 & 15.6 & 42.2 & 26.6 & 9.4 \\
\hline Cost advantages & 64 & 3.16 & 1.130 & 12.5 & 12.5 & 28.1 & 40.6 & 6.3 \\
\hline Profit margin & 64 & 2.63 & 1.228 & 9.4 & 28.1 & 40.6 & 15.6 & 6.3 \\
\hline Average & & 3.31 & & & & & & \\
\hline
\end{tabular}

A small firm can easily compete with big firms by using different designs or using traditional methods. Furthermore, firms' different capabilities vary much, so to predict competitors' power is such a difficult task. Related to characteristics of sector, new product can easily enter to the market and these products can easily be imitated by the rival firms which are also considered as a big threat for the firms.

Other threats such as global threats, domestic threats, and threats related to Turkey's EU candidacy etc., are considered relatively less risky.

Table 2

Perception of Intensity of Competition

\begin{tabular}{llllrrrrr}
\hline & $N$ & Aver. & Std. Dev. & \multicolumn{1}{c}{1} & \multicolumn{2}{l}{3} & \multicolumn{2}{l}{5} \\
\hline Growth of the industry & 64 & 3.47 & 1.154 & 9.4 & 9.4 & 21.9 & 43.8 & 15.6 \\
Existing fierce competition & 64 & 3.38 & 1.351 & 12.5 & 15.6 & 18.8 & 28.1 & 25.0 \\
Imbalanced powers of rivals & 64 & 3.28 & 1.188 & 6.3 & 12.5 & 37.5 & 28.5 & 15.6 \\
Speed of new product entrance & 64 & 3.14 & 0.924 & 3.1 & 17.2 & 51.6 & 18.8 & 9.4 \\
Global threats & 64 & 2.73 & 0.983 & 12.5 & 25.0 & 43.8 & 15.6 & 3.1 \\
Domestic threats & 64 & 2.72 & 0.845 & 9.4 & 21.9 & 59.4 & 6.3 & 3.1 \\
Threats related to Turkey's EU candidacy & 64 & 2.41 & 1.365 & 32.8 & 28.1 & 17.2 & 9.4 & 12.5 \\
Internal risks against rivals & 64 & 2.39 & 1.048 & 20.3 & 35.9 & 34.4 & 3.1 & 6.3 \\
Risk of market shrink & 64 & 2.38 & 1.000 & 21.9 & 31.3 & 37.5 & 6.3 & 3.1 \\
Ability to shift other markets & 64 & 2.22 & 1.374 & 37.5 & 34.4 & 12.5 & 0.0 & 15.6 \\
Regional threats & 64 & 2.22 & 1.000 & 28.1 & 31.3 & 34.4 & 3.1 & 3.1 \\
Possibility of reconciliation with opponents & 64 & 2.22 & 1.175 & 31.3 & 34.4 & 25.0 & & 9.4 \\
Average & & 2.71 & & & & &
\end{tabular}

Perception of threat of substitute goods. Characteristically, Ceramic sector is open to all kinds of substitute goods. For this reason, answers to questions related to perception of threat of substitute goods are almost alike with each other. Only, "the availability of substitute goods" is seen as a more threatening factor than the other factors. Members of the sector indicate that Chinese products and their substitutes are a real threat to them, in terms of availability, market penetration and price etc.. Sector is widely used in imported inputs during the production and a whole range of substitute products are available in the market. In addition to Chinese product's threat, agreement about the custom union with EU is also considered as a serious threat even though it seems like an opportunity. 
Table 3

Perception of Threat of Substitute Goods

\begin{tabular}{llllrrrrr}
\hline & $N$ & Aver. & Std. Dev. & \multicolumn{1}{c}{1} & \multicolumn{2}{l}{3} & \multicolumn{1}{l}{5} \\
\hline Availability of substitute goods & 64 & 3.22 & 0.967 & 6.3 & 6.3 & 59.4 & 15.6 & 12.5 \\
Penetration of substitute goods & 64 & 3.09 & 0.811 & 3.1 & 12.5 & 62.5 & 15.6 & 6.3 \\
Rate of imported inputs & 64 & 3.08 & 1.088 & 9.4 & 17.2 & 39.1 & 25.0 & 9.4 \\
Rate of imported inputs in substitute goods & 64 & 3.06 & 1.006 & 9.4 & 12.5 & 46.9 & 25.0 & 6.3 \\
Price of substitute goods & 64 & 3.00 & 1.155 & 12.5 & 15.6 & 43.8 & 15.6 & 12.5 \\
Variety of substitute goods & 64 & 2.89 & 0.758 & 1.6 & 26.6 & 56.3 & 12.5 & 3.1 \\
Quality of substitute goods & 64 & 2.53 & 1.098 & 18.8 & 31.3 & 34.4 & 9.4 & 6.3 \\
Average & & 2.98 & & & & & \\
\hline
\end{tabular}

Table 4

Evaluation of Bargaining Power of Buyers

\begin{tabular}{|c|c|c|c|c|c|c|c|c|}
\hline & $N$ & Aver. & Std. Dev. & 1 & 2 & 3 & 4 & 5 \\
\hline Importance of price for buyers’ preferences & 64 & 4.06 & 1.258 & 6.3 & 9.4 & 9.4 & 21.9 & 53.1 \\
\hline Importance of quality for buyers' preferences & 64 & 3.81 & 1.052 & 6.3 & 0.0 & 28.1 & 37.5 & 28.1 \\
\hline Barging power of buyer & 64 & 3.66 & 1.087 & 3.1 & 12.5 & 25.0 & 34.4 & 25.0 \\
\hline Importance of good for buyers & 64 & 3.61 & 1.177 & 9.4 & 4.7 & 25.0 & 37.5 & 23.4 \\
\hline Numbers of buyers & 64 & 3.50 & 0.943 & 6.3 & 6.3 & 25.0 & 56.3 & 6.3 \\
\hline Reliability of buyers & 64 & 3.48 & 1.247 & 12.5 & 6.3 & 21.9 & 39.1 & 20.3 \\
\hline Risk of buyers' making agreement with the rivals & 64 & 3.19 & 1.367 & 12.5 & 25.0 & 15.6 & 25.0 & 21.9 \\
\hline Frequency of changes in buyers decisions & 64 & 3.08 & 1.264 & 12.5 & 20.3 & 31.3 & 18.8 & 17.2 \\
\hline Buyers' affects on product development & 64 & 3.00 & 1.069 & 9.4 & 21.9 & 34.4 & 28.1 & 6.3 \\
\hline Average & & 3.49 & & & & & & \\
\hline
\end{tabular}

Table 5

Evaluation of Bargaining Power of Sellers

\begin{tabular}{llllrrrrr}
\hline & $N$ & Aver. & Std. Dev. & \multicolumn{1}{l}{ 1 } & \multicolumn{2}{l}{3} & \multicolumn{1}{l}{5} \\
\hline Affects of supply system on cost & 64 & 3.55 & 0.872 & 1.6 & 4.7 & 46.9 & 31.3 & 15.6 \\
Risk of increase in input prices & 64 & 3.48 & 1.002 & 3.1 & 9.4 & 40.6 & 36.1 & 18.8 \\
Number of suppliers & 64 & 3.45 & 0.975 & 1.6 & 14.1 & 37.5 & 31.3 & 15.6 \\
Cost of transportation & 64 & 3.39 & 1.149 & 9.4 & 9.4 & 29.7 & 35.9 & 15.6 \\
Suppliers' abilities to fulfill sales agreement & 64 & 3.25 & 0.943 & 6.3 & 6.3 & 53.1 & 25.0 & 9.4 \\
Availability of raw material & 64 & 3.14 & 0.900 & 0.0 & 25.0 & 46.9 & 18.8 & 9.4 \\
Risk of delays in supply systems & 64 & 3.06 & 1.037 & 9.4 & 15.6 & 40.6 & 28.1 & 6.3 \\
Availability of suppliers & 64 & 2.94 & 0.710 & 3.1 & 18.8 & 59.4 & 18.8 & 0.0 \\
Possibility of delays from suppliers & 64 & 2.94 & 0.871 & 3.1 & 21.9 & 62.5 & 3.1 & 9.4 \\
Possibility of rivals' pressures on suppliers & 64 & 2.86 & 1.009 & 9.4 & 21.9 & 46.8 & 15.6 & 6.3 \\
Risk of delays in distribution systems & 64 & 2.78 & 0.863 & 9.4 & 18.8 & 59.4 & 9.4 & 3.1 \\
The length of contracts with suppliers & 64 & 2.68 & 0.946 & 15.6 & 18.8 & 48.5 & 17.2 & 0.0 \\
Average & & 3.13 & & & & &
\end{tabular}

During the interviews, many of the ceramic sector mangers/owners indicated that they were pretty much confident about their product quality. They say that substitute goods are a real threat to them in every mean except the quality wise.

Evaluation of bargaining power of buyers. As mentioned before, there is a huge variety of products produced by a variety of firms in the market. Hence, the buyers could easily compare the prices and the 
qualities of mass produced goods which enhances the power of buyers. The ceramic producers feel that the price of products is the main threat for them, except a producer who was producing artistic works, mentioning that price does not create a pressure on him.

In addition to price pressure, other factors like costs of goods, quality, product diversity, and flexibility are also affect the power of buyers. In interviews, the balance between the price and quality was one of the main subjects that firms' managers/owners mentioning. Buyers' affect on product development can be seen as a least threatening factor because they have already adapted to the market conditions which require high product variety and flexible production methods.

Evaluation of bargaining power of sellers. Affects of supply system on cost is the highest threat to the ceramic sector because sector is highly competitive and price sensitive sector. Changes in cost of raw materials and supplementary expenditures affect the prices, as a result it affects competitiveness. Even though, there is a plenty of raw materials in Turkey and the price of such inputs' prices is considerably cheap, fluctuations in the prices affect their competitiveness. Especially companies whose target markets are foreign markets are complaining about the value of Turkish Liras (they consider it too high), which relatively increases costs including transportation and other costs.

Suppliers mostly are able to fulfill their promises, but in some cases technical problems: such as gaps in the agreement, timing of delivery and storing materials are arising as factors which are reducing their effectiveness and competitiveness of the firms.

The lowest degree of threat comes from the length of contracts with suppliers. Generous amount of supplementary sources make ceramic firms powerful against to suppliers that is why suppliers prefer to extend the length of the contracts by themselves. In parallel to this, rivals’ pressures on suppliers are quite low.

\section{Conclusions and Summary}

Policy-makers and decision-makers are needed to have correct information that suitable to analyze existing situation, as well as the sector's managers/owners. But, having (hundred percent) correct information which is also suitable for analyses is almost impossible. That is why academicians are trying improving existing theories or methods continuously. In terms of sector analyses, Porter's five forces model is one of the most respected models. Our study is trying to produce more suitable information about the Turkish ceramic sector in the light of Porter's five forces model.

Turkey, as a candidate country for EU membership, has to adapt and prepare its sectors for more competitive European market. For these reasons Turkish policy makers and the sector members should design better strategies which require correct information that suitable to analyze. This study might help them in this perspective.

Result of the study indicates that the size of labor force significantly affects the competitiveness of the firms, unlike the size of capital and turnover where there is no significant difference.

The other results of the study related to internal competitiveness of firms could be listed as follows: according to the labor force criterion, $56.3 \%$ of the firms can be considered as small firms; according to capital size criterion, $90.3 \%$ of the firms can be considered as small firms; and according turnover size criterion, 93.8\% of the firms can be considered as small firms.

In the long term their target is to be the leader in the industry and they are trying to integrate both horizontally and vertically. There are already strong clusters existing and the numbers of clusters are rising. 
They are more focused on international markets, $80 \%$ of the firms are managed by professional managers including $25 \%$ of them completely managed by professionals. Mangers have at least undergraduate degree, $68.8 \%$ of ceramic producers' main target is to prove customers satisfaction.

Average capacity utilization rate is $\mathbf{8 5 . 9 \%}$ which is relatively high in comparison to other sectors. Majority of the firms are using several information technologies heavily. But very few of them are using modern production systems, in this regard, they are a bit behind the international rivals. Quality management and quality assurance systems are used widely and there is an accelerated trend on research and development facilities which indicates that they are forcing to be more competitive.

In the second phase of the study, firms' perspectives on possible threats assessed in the light of Porter's five forces model. Some of the results are: there is a meaningful relationship between ceramic sector and its sub sectors in terms of labor force legal structure, management structure. Ceramic companies' primary threat perceptions are "product diversity" and "developments in R\&D" which means that they have recognized the importance of R\&D facilities for product development even though they do not invest in R\&D facilities yet.

Perception of ceramic producers on intensity of competition can be interpreted as-there is a fierce competition. Because, they feel that sector is growing, there is a destructive competition between the rivals and there is an imbalanced power between the opponents. Availability of substitute goods and their penetration rates are considered as major threats for the ceramic producers.

Buyers of the sector have certain powers over the producers, which are coming into sight in price competition and quality. Suppliers' powers over the buyers are centered on price and its effects on costs, and numbers of the suppliers. This is because product price plays such an important role in competition which is forcing firms to focus on cost-oriented production.

\section{References}

Arons, H. S., \& Waalewijn, P. (2000). A knowledge base representing porter's five forces model. Retrieved February 12, 2008, from http://www.Publishing.Eur.Nl/Ir/Repub/Asset/753/Eur-Few-Cs-99-02.Pdf

Bain, J. (1968). Industrial organization. Wiley: New York.

Boulding, W., Moore, M. C., Staelin, R., Corfman, K. P., Dickson, P. R., Fitzsimons, G., ... Weitzm, B. A. (1994). Understanding managers’ strategic decision-making process. Marketing Letters, 5(4), 413-426.

Certo, S. C., \& Peter, P. J. (1995). The strategic management process. Chicago: Irwin.

Chaffey, D. (2002). E-business and e-commerce management: Strategy, implementation and practice. UK: Prentice Hall.

Coşkun, R. (2001). Using porters's five forces model in strategic industry analysis of SMEs. National Management and Organization Congress, Istanbul-Silivri, Adapazar1-Turkey.

Dess, G. G., \& Miller, A. (1996). Strategic management (2nd ed.). New York: McGraw Hill.

Eleren, A., \& Kayahan, C. (2008). The competition analyses in Turkish industry in the light of PORTER's five forces competition scale. Afyonkarahisar: AKÜ Publication.

Eroğlu, Ö., \& Özdamar, G. (2006). Competitiveness of the Turkish manufacturing industry and a study on the household appliances industry. Journal of Business Administration and Economy, 11, 85-104.

European Commission (1994). An industrial competitiveness policy for the european union. Bulletin of the European Union. Luxembourg. OOPEC.

Hatsaopulos, G., Krugman, P., \& Summer, L. (1988). U.S. competitiveness: Beyond the trade deficit. Science, 241(4863), 299-307.

Hitt, M. A., Dacin, M. T., Tyler, B. B., \& Park, D. (1997). Understanding the differences in Korean and U.S. executives’ strategic orientations. Strategic Management Journal, 18(2), 159-167.

Kotan, Z. (2002). Indicators of international competitiveness: Sample of Turkey. TCMB Araştırma Genel Müdürlü̆̆̈̈, Ankara.

Kotler, P. (2000). Marketing management: Analysis, planning, implementation and control. Englewood Cliffs, N.J.: Prentice-Hall. 
Mansfield, E. (1993). The diffusion of flexible manufacturing systems in Japan, Europe, and the United States. Management Science, 39(2), 149-160.

Miller, D., \& Freisen, P. H. (1984). Organisations: Aquantum view. Englewoodcliffs, N.J.: Prentice Hall.

Peteraf, M. A. (1993). The cornerstones of competitive advantage: A resource-based view. Strategic Management Journal, 14, 179-191.

Porac, J. F., \& Thomas, H. (1990). Taxonomic mental models in competitor definitions. Academy of Management Review, 15(2), 224-240.

Porter, M. E. (1980). Competitive strategy. New York: Free Press.

Porter, M. E. (1989). Strategy in deal-based industries. Remarks to the 1989 HBS Real Estate.

Porter, M. E. (1996). What is strategy. Harvard Business Review, 74(6), 61-78.

Porter, M. E. (1998). Clusters and the new economic of competition. Harward Business Review, 76(6), 77-90.

Porter, M., \& Millar, V. E. (1985). How information gives you competitive advantage. Harward Business Review, 63(4), $149-160$.

Ralston, D. A., Gustafson, D. J., Cheung, F. M., \& Terpstra, R. H. (1993). Differences in managerial values: A study of U.S., Hong Kong, and PRC managers. Journal of International Business Studies, 24(2), 233-249.

Scherer, F. M., \& Ross, D. (1990). Industrial market structure and economic performance (3rd ed.). Boston: Houghton-Mifflin.

Scoot, B. R., \& Lodge, C. (1985). US competitiveness in the world economy. Boston: Harvard Business School Press.

Sultan, S. S. (2007). The competitive advantage of small and medium sized enterprises: The case of Jordan's natural stone industry. Retrieved December 12, 2007 from http://www.Merit.Unu.Edu/Training/Theses/Ssultan.Pdf

Utterback, J. M., \& Abernathy, W. J. (1975). A dynamic model of product and process innovation. Omega, 3, 639-656. 